\title{
Spatial subsidy in the subtidal zone: utilization of drift algae by a deep subtidal sea urchin
}

\author{
Kevin H. Britton-Simmons ${ }^{1, *}$, Gerard Foley ${ }^{1}$, Daniel Okamoto ${ }^{1,2}$ \\ ${ }^{1}$ University of Washington, Friday Harbor Laboratories, 620 University Road, Friday Harbor, Washington 98250, USA \\ ${ }^{2}$ Present address: University of Alaska Fairbanks, School of Fisheries and Ocean Sciences, Juneau Center, \\ 11120 Glacier Highway, Juneau, Alaska 99801, USA
}

\begin{abstract}
Spatial subsidies link adjacent habitats and can have strong effects on recipient systems. Within temperate nearshore marine ecosystems, algae dominate rocky benthic communities in the shallow subtidal but are supplanted by invertebrates at deeper depths where light becomes limiting. Detrital macrophytes transported into deep subtidal habitats by hydrodynamic forces may subsidize deep organisms, but little is known about the availability or utilization of this organic material. We used descriptive field studies to study drift macrophyte utilization by the red urchin Strongylocentrotus franciscanus, a commercially harvested species found in both shallow and deep habitats in Washington, USA. Our primary goals were to evaluate urchin diet, urchin fecundity, and drift macrophyte abundance in the deep subtidal zone (>20 m depth). Although seasonally variable, macrophyte detritus was present year-round in the deep subtidal (23 $\mathrm{m}$ depth) and diet data suggest it is the primary food resource for deep subtidal red urchins. Perennial kelps were the main contributors to the detrital pool (54\% of biomass), particularly the shallow subtidal species Saccharina subsimplex ( $37 \%$ of biomass). At 4 of our 5 study sites, red urchins from deep habitats had gonad indices as large as sea urchins from shallow habitats, suggesting that drift algae are an abundant food resource in the deep subtidal zone of our study region. A comparison of our results with previous studies indicates that the availability of macroalgal detritus in the deep subtidal varies considerably in space and may be influenced by the hydrodynamic context. We suggest that successful management of subsidized species may require understanding subsidy sources and fluxes because changes in the production or delivery of organic material can have important consequences for recipient populations.
\end{abstract}

KEY WORDS: Drift kelp · Strongylocentrotus franciscanus · Macroalgal detritus · Allochthonous input

\section{INTRODUCTION}

In recent decades ecologists have increasingly recognized that fluxes of energy and nutrients between adjacent habitats (spatial subsidies) play a key role in structuring natural communities (Polis et al. 1997, Nakano \& Murakami 2001). These spatial subsidies supplement endogenous sources of carbon and nutrients and often have important population-level consequences for recipient species (Bustamante et al. 1995, Rose \& Polis 1998, Sanchez-Pinero \& Polis 2000). Moreover, indirect effects propagated via trophic interactions can result in broader community and food web consequences, including top-down (Polis \& Hurd 1995, Rodriguez 2003) and bottom-up effects (e.g. Bosman \& Hockey 1986, 1988, Polis \& Hurd 1996, Stapp \& Polis 2003).

In temperate marine ecosystems, benthic primary productivity is restricted to shallow nearshore habitats because light becomes limiting in deeper waters. The productivity of these benthic algal communities can be extremely high, rivaling or exceeding the most productive ecosystems, particularly in regions where kelps are the dominant seaweeds (Leigh et al. 1987, Witman 1988). However, only about $10 \%$ of algal biomass is consumed directly by herbivores (Mann 1988), the 
remainder enters subtidal (Dunton \& Schell 1987, Duggins et al. 1989), intertidal (Rodriguez 2003), pelagic (Kaehler et al. 2006) and terrestrial food webs (Polis \& Hurd 1995) as detritus. This algal-derived carbon exists in a continuum of sizes, ranging from entire plants to dissolved organic matter. The largest of these forms includes entire plants and fragments thereof, collectively referred to as drift algae. The transport of drift algae by currents and waves from the shallow subtidal zone into adjacent habitats constitutes a substantial flux of detrital organic matter (Orr et al. 2005) and can have important consequences for the recipient systems (Bustamante et al. 1995, Polis \& Hurd 1995).

The deep subtidal is unique among systems that receive inputs of drift algae because it has no source of endogenous primary productivity. Although fluxes of drift macrophytes into the subtidal have been described for decades (Menzies et al. 1967, Josselyn et al. 1983, Suchanek et al. 1985), the focus of previous work has been on documenting the accumulation of this biomass and associated organisms in deep sink areas such as submarine canyons (Josselyn et al. 1983, Harrold et al. 1998, Vetter \& Dayton 1999). As drift algae move between shallow source and deep sink areas, this represents a potentially valuable food resource. However, both the spatial and temporal dynamics of drift fluxes and the population and community level consequences of this type of subsidy are poorly understood.

In the San Juan Archipelago, Washington, USA, shallow subtidal habitats are dominated by a speciesrich, multilayered algal community that includes a canopy of brown algae and an understory of red algae (see Britton-Simmons 2006 for a detailed description). The largest herbivore in this system is the red urchin Strongylocentrotus franciscanus, a species that can grow to more than $15 \mathrm{~cm}$ in diameter and that is harvested commercially for its gonads. Red urchins are common in the shallow, algal-dominated subtidal zone, but their distribution extends to depths of more than 100 m (D. Duggins pers. comm.). Attached macroalgae are virtually absent in the deep subtidal, operationally defined for the present study as depths greater than 20 m mean lower low water (MLLW). Our preliminary field observations indicated that red urchins in these habitats were feeding on drift algae. However, the seasonal availability of drift algae was unknown and it was unclear whether deep-dwelling red urchins were supplementing their algal diet with autochthonous food resources (e.g. benthic invertebrates). Thus, one purpose of the present study was to investigate the red urchin diet and the availability of drift algae in the deep subtidal zone.

The broad depth range inhabited by red urchins includes habitats that differ in important physical and biological attributes. Previous work in Bodega Bay,
California, demonstrated that shallow-dwelling red urchins had gonad masses 4 times the size of deepdwelling red urchins, suggesting that food limits fecundity in deep subtidal habitats (Rogers-Bennett et al. 1995). In the San Juan Islands, the harvesting of red urchins has moved into deeper ( $>20 \mathrm{~m}$ depth) waters in recent years (Pfister \& Bradbury 1996, B. Sizemore pers. comm.), but little is known about the ecology of deep-dwelling red urchins. Therefore, a second purpose of the present study was to evaluate whether depth-related differences in red urchin gonad mass exist in our study area.

We used a series of descriptive field studies to study drift algae and red urchins in subtidal zones of the San Juan Islands. Specifically, we addressed 4 main questions: (1) What is the diet of red urchins in the deep subtidal zone? (2) Do deep-dwelling red urchins have small gonads relative to shallow-dwelling red urchins? (3) Is there seasonal variation in the abundance of drift algae in the deep subtidal zone? and (4) Are there differences in red urchin abundance between depths?

\section{MATERIALS AND METHODS}

Study sites. The present study was based from Friday Harbor Laboratories in the San Juan Archipelago, Washington, USA. Our 7 study sites were located in the nearshore waters of Shaw and San Juan Islands (Fig. 1) within an area closed to sea urchin harvesting. Most of our study sites were also within 2 large marine protected areas established in 1991.

The nearshore habitat in this region is dominated by spatially complex, rocky habitats that transition into soft, mixed substrate habitats at depth (typically below $30 \mathrm{~m}$ ). Although protected from ocean swells, the San Juan Archipelago experiences locally generated wind waves and strong, tidally generated currents.

Red sea urchin diet in the deep subtidal zone. We addressed Question 1 using 3 approaches: (1) vertical transects at 3 sites to document the availability of attached macroalgae in shallow and deep habitats, (2) in situ feeding surveys at 7 sites to evaluate the availability and identity of food items utilized by deepdwelling red urchins, and (3) gut content data from 5 sites over 1 yr to provide detailed, seasonal information about deep-dwelling red urchin diet.

Vertical transects: A single vertical transect was surveyed at each of 3 sites (Pt. Caution, Pt. George, and Roddy's Reach, see Fig. 1) in August of 2006. Upon entering the water the divers descended immediately to a depth $30.5 \mathrm{~m}$ below MLLW and haphazardly selected a $900 \mathrm{~cm}^{2}$ plot to survey. After surveying that plot the divers ascended $3.05 \mathrm{~m}$ (perpendicular to the shoreline) and surveyed a second plot directly above 


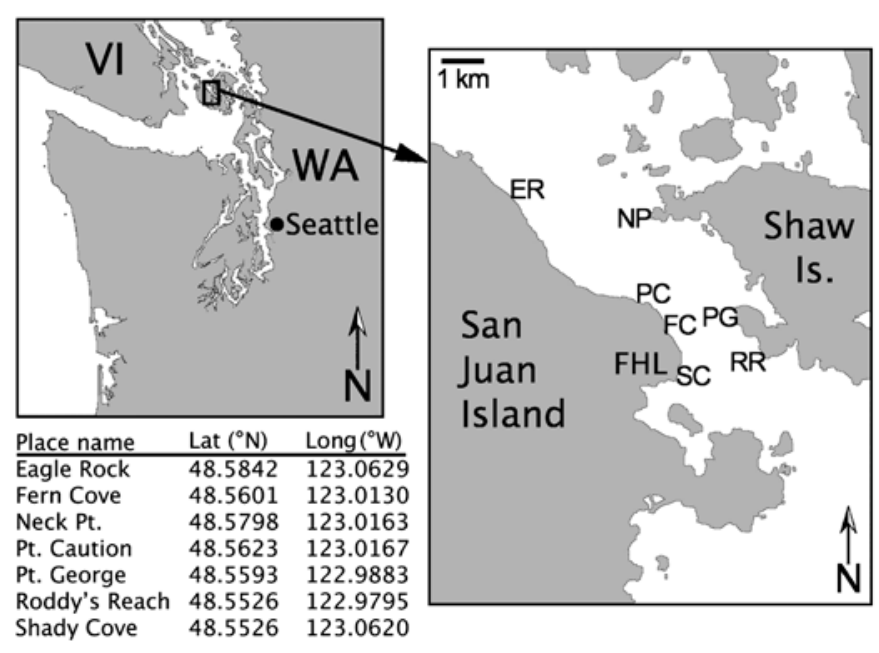

Fig. 1. Study sites in the San Juan Archipelago, Washington, USA. Large-scale map shows the entire marine coastline of Washington and the southern portion of Vancouver Island, Canada. WA: Washington; VI: Vancouver Island; FHL: Friday Harbor Laboratories. Site abbreviations are as follows: Eagle Rock (ER), Fern Cove (FC), Neck Pt. (NP), Pt. Caution (PC), Pt. George (PG), Roddy's Reach (RR) and Shady Cove (SC)

the first one. This procedure was repeated until reaching a depth of $0 \mathrm{~m}$ below MLLW.

All surveys were carried out on hard rock substrate with a slope of less than 45 degrees. Steeply sloped rocks and non-rock substrata were excluded a priori. When non-rock or steeply sloped substrata were encountered, divers simply moved laterally to the nearest suitable substrate and continued the survey. The purpose of these surveys was to document changes in algal abundance that occur with depth in this study system. Thus, we wanted to exclude areas that had recently been grazed by sea urchins because the benthic algal community can be dramatically altered in these areas. When sea urchins were encountered, divers moved laterally until reaching a distance of $1 \mathrm{~m}$ from the nearest sea urchin and continued the survey. We were unable to sample one depth $(6.1 \mathrm{~m})$ at Pt. Caution because it fell within an urchin barren.

For each plot we first estimated the percent canopy cover of kelp, we then gently moved the kelp aside and estimated the percent canopy cover of fleshy red algae (e.g. Plocamium, Rhodoptilum). We counted the number of kelps and estimated the percent of primary space that was occupied by algae (all taxa combined), coralline algae, and invertebrates. Because we were specifically interested in space utilization, only benthic, sessile species were included in the invertebrate category.

In situ feeding observations: We made red urchin feeding observations at 7 sites between 28 May and 3 July 2003 (Fig. 1). We selected our in situ feeding study sites based on prior knowledge of the area, focusing on areas where rocky habitat and red urchins were known to occur. At each site we placed a randomly positioned $20 \mathrm{~m}$ transect at a depth of $23 \mathrm{~m}$ below MLLW. Preliminary sampling indicated that sea urchins were often feeding on small pieces of drift algae that were not visible until sea urchins were turned over. Therefore, during our sampling all red urchins within $1 \mathrm{~m}$ of the transect were individually turned over to determine if they were in possession of algae. The total area sampled at each site was $40 \mathrm{~m}^{2}$. In addition, for a subset of the sea urchins $(\mathrm{N}=131)$ that were sampled at each site, we identified to species level all algae that were in their possession. We collected in situ feeding data from a total of 259 red urchins.

Gut contents: We collected red urchins from 5 sites at approximately quarterly intervals over the course of 1 yr (Pt. Caution, Pt. George, Roddy's Reach, Shady Cove, and Eagle Rock, Fig. 1). These sites were chosen from the pool of 7 sites at which in situ feeding data were collected so that sites representing the full range of in situ feeding results were represented. Samples were collected in July/August 2003, November 2003, February/March 2004, and May 2004. Sea urchins were sampled at $5 \mathrm{~m}$ and $23 \mathrm{~m}$ below MLLW (6.4 and $24.4 \mathrm{~m}$ water depth at an average tidal height) by laying a randomly placed $20 \mathrm{~m}$ transect at the target depth and collecting sea urchins that were closest to randomly chosen numbers along the transect. We selected these depths for 2 reasons. First, they correspond to the shallowest and deepest depths sampled in a similar study in California (Rogers-Bennett et al. 1995) and, therefore, we have a basis for comparison with their results. Second, in our system these depths represent habitats that are within and below the algae-dominated zone (Fig. 2a). During the first 3 sample periods we collected 5 sea urchins per depth at each site, but we reduced this number to 3 sea urchins per depth during the final sample period (May 2004). Sea urchins were returned to the lab and processed individually as described in this and the following sections. Response variables were measured on all sample dates unless otherwise noted.

The gut contents of each red urchin were searched thoroughly to determine whether invertebrates, algae, or sediment were present. All invertebrates encountered were identified to the lowest possible taxonomic level.

Gonad size of deep-dwelling vs. shallow-dwelling red sea urchins. To address this question we collected gonad mass information from all red urchins collected for gut content analyses (see previous section for detailed collection information). Gonad material was 

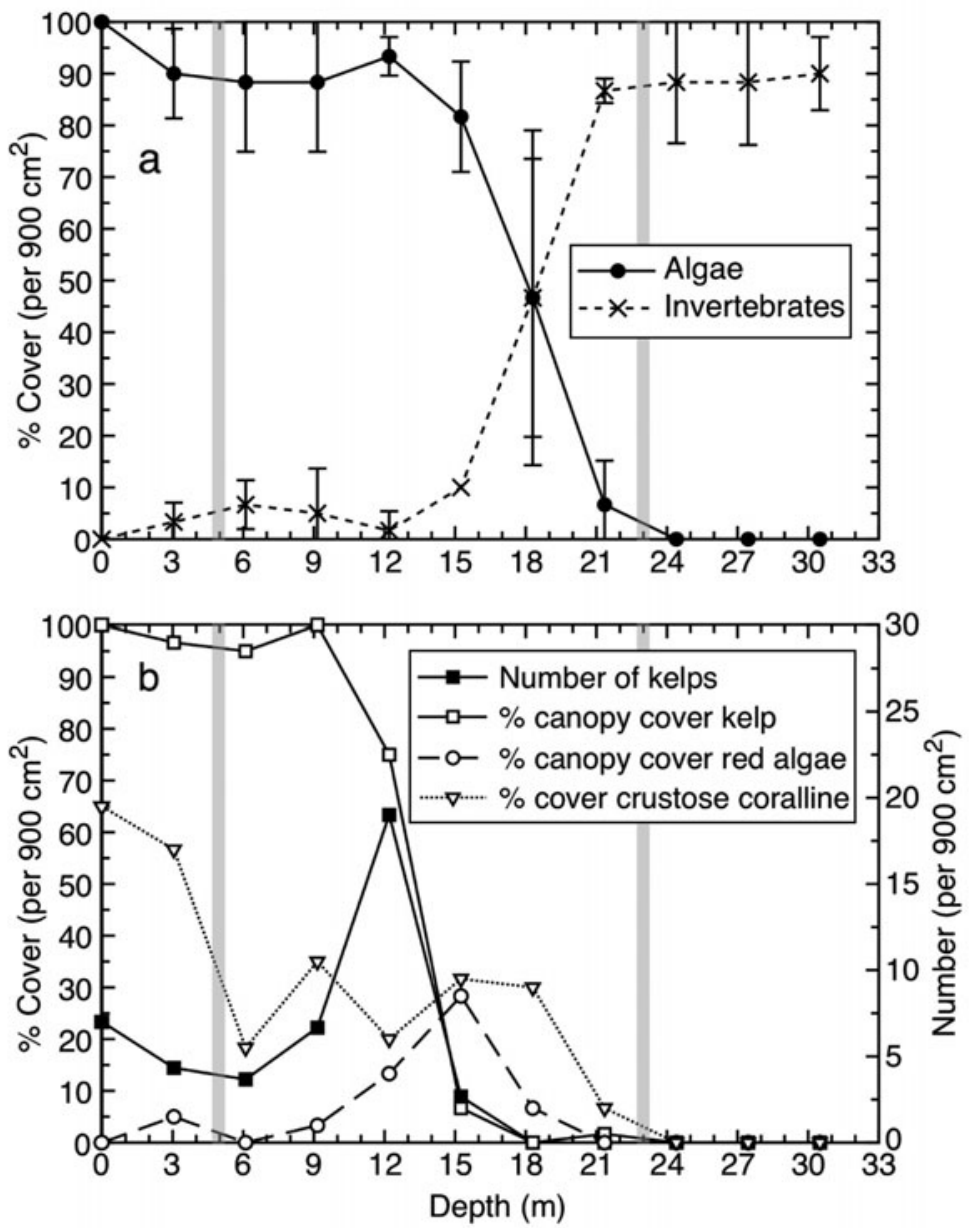

Fig. 2. Vertical transect data from 3 sites showing the (a) percent cover of primary space occupied by attached algae and invertebrates and (b) abundance (percent cover or number) of different algal groups as a function of depth (m below mean lower low water) in the subtidal zone. Vertical grey bars indicate the depths from which red sea urchins were sampled. The \% canopy cover red algae data includes erect, fleshy red species only. Data plotted are (a) mean \pm SD and (b) mean only (error bars omitted for clarity)

removed, blotted to remove excess water, and weighed to $0.1 \mathrm{~g}$. In addition, test diameter and total wet body mass of each sea urchin was measured. Because gonad size covaries with sea urchin size, we calculated a gonad index by dividing gonad mass by total body mass (Keats et al. 1984, Harrold \& Reed 1985, Wahle \& Peckham 1999). However, our statistical results were the same regardless of whether gonad mass was normalized by test diameter or body mass.

Drift algal abundance in the deep subtidal zone. During the sea urchin collection dives we collected all drift vegetation (algae and seagrass) within $1 \mathrm{~m}$ of the deep transect, including pieces that had already been captured by sea urchins. These specimens were returned to the lab, identified to species level, and weighed to the nearest mg (wet mass).
Red sea urchin abundance. We quantified red urchin abundance by counting all red urchins within $1 \mathrm{~m}$ of our $20 \mathrm{~m}$ transect (total area of $40 \mathrm{~m}^{2}$ ) at both depths at each of our 5 sites in November of 2003.

Statistical analyses. The red urchin abundance data were analyzed using a paired $t$-test to determine whether sea urchin abundance differed between deep and shallow habitats. The abundance data were natural log transformed prior to analysis to achieve homogeneity of variance.

We carried out a 3-way, fully factorial ANOVA with site, depth, and time as main effects on the arcsin-square root transformed gonad index data. We tested the homogeneity of slope assumption for ANCOVA by initially running a fully factorial, 3-way ANCOVA model that also included an interaction term for each main effect crossed with the covariate (Engqvist 2005). In all cases these interaction terms were non-significant $(\alpha=0.05)$, indicating that the homogeneity of slope assumption was valid for our data set. We then removed the interaction terms involving the covariate and reanalyzed the gonad index data. Because the 3-way analysis indicated a significant interaction involving depth, we performed separate 2-way ANOVAs (main effects: depth, date) on the gonad index data from each site in order to better understand the interaction term.

We used a 1-way ANOVA to test for seasonal variation in the abundance of drift algae in the deep subtidal. Because our sample sites were the same on all sample dates we used site as a blocking factor in the ANOVA model.

\section{RESULTS}

\section{Red sea urchin diet in the deep subtidal zone}

\section{Vertical transects}

These data illustrate the dramatic changes in community composition with increasing depth in the subtidal zone of this nearshore ecosystem. Shallow communities are dominated by algae (Fig. 2a). Between 15 and $21 \mathrm{~m}$ there is a transition zone where algae rapidly decrease and invertebrates quickly increase in abundance. Below a depth of $20 \mathrm{~m}$ algae are nearly absent and the substratum is dominated by benthic invertebrates (Fig. 2a, see also Neushul 1967). Thus, the depths 
from which red urchins were sampled in the present study represent 2 very different habitats: a shallow habitat where attached algae are abundant and a deep habitat where attached algae are extremely uncommon.

The dominant algae in the shallow zone include kelps (order Laminariales), erect fleshy red algae, crustose coralline algae (Fig. 2b). Kelps are essentially absent by a depth of $15 \mathrm{~m}$ (Fig. 2b), and they typically diminish in size near the lower edge of their vertical distribution. Erect fleshy red algae are still fairly abundant at $15 \mathrm{~m}$, but are uncommon by $18 \mathrm{~m}$. Crustose coralline algae are the deepest growing species in this region where they can be common to depths of $18 \mathrm{~m}$ (Fig. 2b) or even deeper at some sites (K. H. Britton-Simmons pers. obs.).

\section{In situ feeding observations}

A large proportion of deep subtidal red urchins were feeding on drift algae at most sites during our in situ surveys (28 May to 3 July 2003). At 5 of the 7 sites more than $60 \%$ of individuals were in possession of drift algae. The percentage of red urchins in possession of drift algae at each site was: Eagle Rock (63\%), Fern Cove (94\%), Neck Point (89\%), Pt. Caution (84\%), Pt. George (56\%), Roddy's Reach (76\%), and Shady Cove $(33 \%)$. At 4 of the 7 sites some red urchins $($ mean $=12 \%$ ) were in possession of drift algae but were not actively feeding. Overall, $17 \%$ of sea urchins surveyed held multiple pieces of drift algae. Kelp was the most commonly captured type of algae, accounting for $76 \%$ of observations. Saccharina subsimplex (46\% of all observations) was the most frequently recorded kelp species, with Agarum fimbriatum a distant second (15\% of all observations). Non-kelp phaeophyceans accounted for $12 \%$ of the total and the majority of that $(10 \%)$ was Desmarestia spp. Red and green algae represented 7 and $4 \%$ of the total, respectively.

\section{Gut contents}

Algae were present in the guts of 175 (97\%) of the 180 red urchins that were dissected (Table 1). Guts without algae were encountered only in sea urchins collected in the winter 2004 sample and 4 of the 5 sea urchins whose guts did not contain algae were from the deeper depth. We found a considerable amount of sediment in the guts of some sea urchins during the fall (6 individuals) and winter (8 individuals) samples
(Table 1). Sea urchins with sediment in their guts were almost exclusively from deep habitats, with a single exception from the winter sample, when one shallowdwelling sea urchin was found to have consumed sediment.

The most common invertebrate found in red urchin guts was Membranipora membranaceae (9\% of guts, Table 1), an encrusting bryozoan that is common on kelp blades in this region. Examination of the bryozoan colonies clearly showed that they were digested, as evidenced by the empty zoid skeletons we commonly found in sea urchin guts. Other invertebrate parts found inside sea urchin guts included crustacean appendages (1 red urchin, 1\% of guts) and a hydroid theca (1 red urchin, $1 \%$ of guts).

\section{Gonad size of deep-dwelling vs. shallow-dwelling red sea urchins}

The tests of 3 red urchins (2 shallow-dwelling, 1 deep-dwelling) were cracked during collection and transport and we were unable to use the body mass data (or calculate gonad indices) for those individuals.

Not surprisingly there was significant variation among sites in gonad index $(p=0.001)$ (Table 2, Fig. 3). Although the main effect of depth in the 3-way ANOVA was not statistically significant, the signifi-

Table 2. ANOVA analysis of red sea urchin gonad index (gonad mass/total mass)

\begin{tabular}{|lrcrc|}
\hline Source of variation & df & MS & $F$ & $p$ \\
\hline Site & 4 & 0.0077 & 4.68 & 0.001 \\
Depth & 1 & 0.0013 & 0.83 & 0.36 \\
Date & 3 & 0.11 & 69.69 & $<10^{-6}$ \\
Site $\times$ Depth & 4 & 0.0065 & 3.95 & 0.005 \\
Site $\times$ Date & 12 & 0.0017 & 1.07 & 0.39 \\
Depth $\times$ Date & 3 & 0.0031 & 1.89 & 0.13 \\
Site $\times$ Depth $\times$ Date & 12 & 0.0029 & 1.75 & 0.06 \\
Error & 137 & 0.0016 & & \\
\hline
\end{tabular}



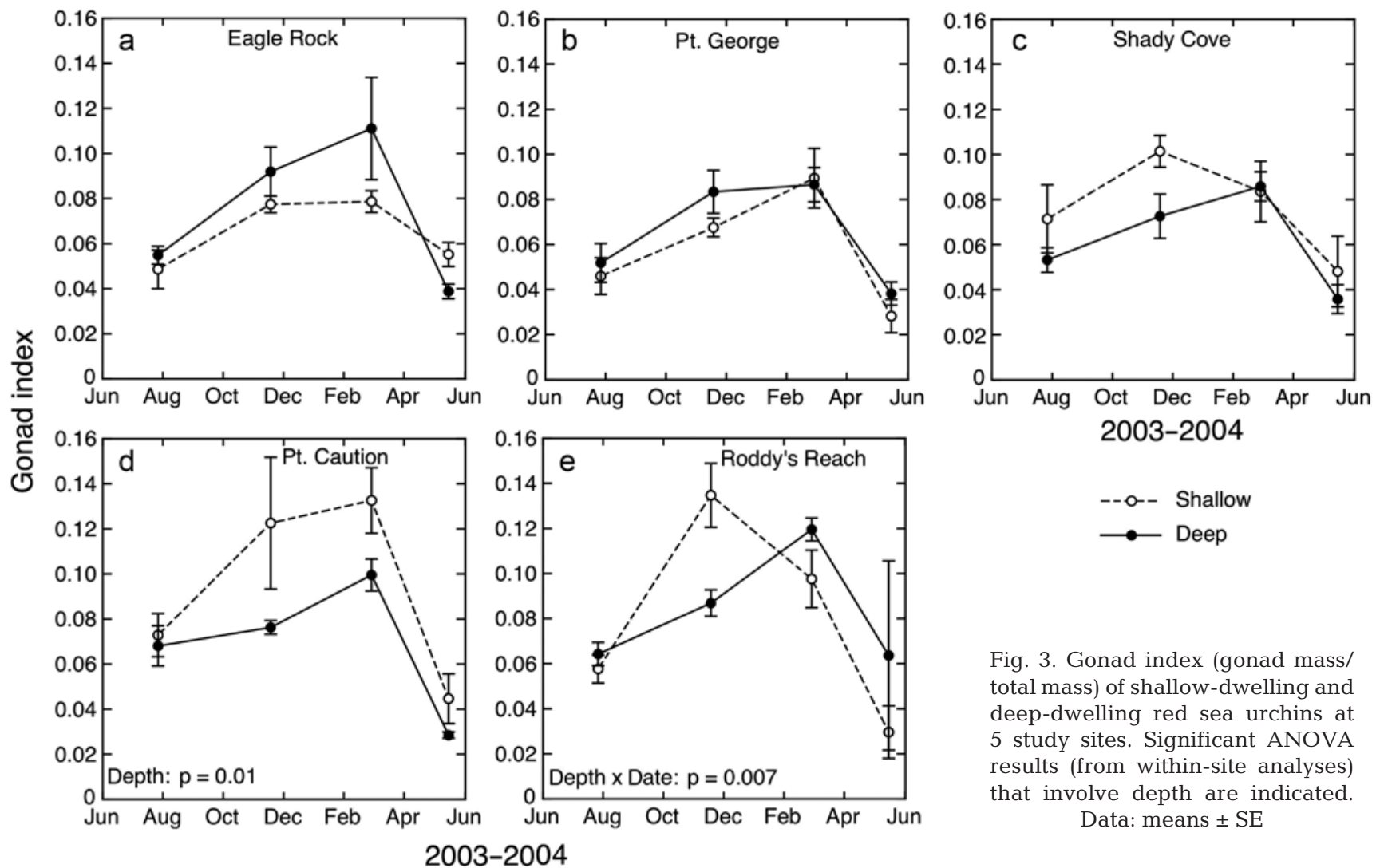

Fig. 3. Gonad index (gonad mass/ total mass) of shallow-dwelling and deep-dwelling red sea urchins at 5 study sites. Significant ANOVA results (from within-site analyses) that involve depth are indicated. Data: means $\pm \mathrm{SE}$

cant site by depth interaction ( $p=0.005)$ indicated that there was a difference in gonad index between depths at one or more sites (Table 2, Fig. 3). In order to explore this interaction we carried out separate, fully factorial, 2-way ANOVAs (main effects: depth, date) on the arcsin-square root transformed gonad index data from each site. These analyses showed that Pt. Caution was the only site at which gonad index differed between depths $\left(F_{1,28}=7.45, \mathrm{p}=0.01\right)$. Mean gonad index was consistently higher in shallow-dwelling sea urchins on all sample dates at Pt. Caution, and, prior to spawning, gonads from shallow-dwelling sea urchins were on average $33 \%$ larger than those from deep-dwelling sea urchins (Fig. 3d). The 2-way ANOVAs also indicated a significant depth by date interaction $\left(F_{3,28}=4.85, \mathrm{p}=0.007\right)$ at Roddy's Reach (Fig. 3e). Shallow-dwelling sea urchins at this site reached their peak gonad size faster, and spawned sooner, than did deep-dwelling sea urchins, but pre-spawning gonad index was similar at both depths (Fig. 3e).

As expected, gonad index varied significantly across sample dates $\left(\mathrm{p}<10^{-6}\right)$ (Table 2, Fig. 3). Gonads generally increased in size during the summer, fall, and winter prior to spawning, which occurred between late February and the middle of May at most sites (Fig. 3).

\section{Drift algal abundance in the deep subtidal zone}

The site blocking factor was removed from the ANOVA model because it did not explain a significant amount of variation in drift biomass. The resulting 1-way ANOVA indicated that there was significant variation in the total mass of drift vegetation among

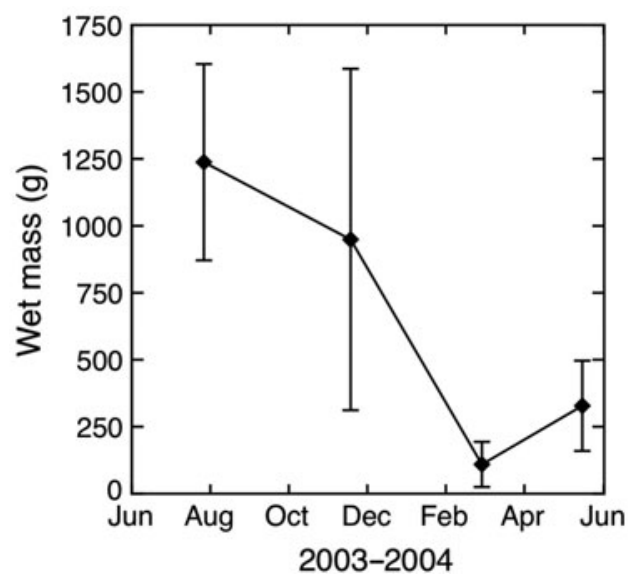

Fig. 4. Mass of drift vegetation (algae and seagrass) sampled from a $40 \mathrm{~m}^{2}$ area at a depth of $23 \mathrm{~m}$ below mean lower low water at 5 study sites (pooled data: Pt. Caution, Pt. George, Roddy's Reach, Shady Cove, Eagle Rock). Data: mean \pm SE 
sample dates $\left(F_{3,16}=4.85, \mathrm{p}=0.01\right)$ (Fig. 4). A post-hoc Tukey's test showed that drift biomass in March was significantly lower than in July $(\mathrm{p}=0.01)$ and was nearly significantly lower than in November $(p=0.05)$. All other pairwise comparisons among sample dates were non-significant. There were only 2 zeros in this data set (Eagle Rock and Pt. George) and both occurred during March. Notably, those 2 sites had the highest abundance of drift on the previous sample date, in November.

Kelps (order Laminariales) were the largest contributor to drift vegetation, accounting for $71 \%$ (Table 3). Collectively, brown algae made up $88 \%$ of the drift biomass, with $63 \%$ of the total attributable to perennial brown algae (Table 3). The 3 main contributors in terms of biomass were Saccharina subsimplex (37\%), Agarum fimbriatum (11\%), and Fucus distichus (9\%). Despite their abundance in the shallow subtidal in this region, 2 species with pneumatocysts (Nereocystis luetkeana and Japanese seaweed Sargassum muticum) were relatively minor constituents of the drift vegetation (Table 3). However, Fucus distichus, which also has floats, made up $9 \%$ of total drift biomass. It is important to note that our drift collections included algae already captured by sea urchins. Therefore, to the extent that sea urchins are selective about which species they capture, our data may be a biased picture of the species composition of drift vegetation at these sites.

\section{Red sea urchin abundance}

The abundance of red urchins in shallow habitats $\left(1.8 \pm 2.2 \mathrm{~m}^{-2}\right.$, mean $\left.\pm \mathrm{SD}\right)$ was twice that of abundance in deep habitats $\left(0.8 \pm 0.6 \mathrm{~m}^{-2}\right)$. However, this difference was not significant $\left(t_{4}=0.80, \mathrm{p}=0.47\right.$ ) due to high variability at both depths. The shallow sea urchin abundance data were particularly variable because one of our shallow sites (Pt. Caution) was within an urchin barren, where density was more than 3 times higher than at any other shallow site.
Table 3. Species composition of drift vegetation (algae and seagrass) collected from a depth of $23 \mathrm{~m}$ below mean lower low water. Data from 5 study sites (Pt. Caution, Pt. George, Roddy's Reach, Shady Cove, Eagle Rock) and 4 sampling dates (July/August 2003, November 2003, February/March 2004, May 2004) are combined

\begin{tabular}{|c|c|c|c|}
\hline Taxon & $\begin{array}{l}\text { Wet mass } \\
(\mathrm{g})\end{array}$ & $\begin{array}{c}\text { Proportion } \\
\text { of total }\end{array}$ & Life history \\
\hline Laminariales (kelps) & 9248.6 & 0.71 & \\
\hline Saccharina subsimplex ${ }^{a}$ & 4870.9 & 0.37 & Perennial \\
\hline Agarum fimbriatum & 1396.5 & 0.11 & Perennial \\
\hline Costaria costata & 556.4 & 0.04 & Annual \\
\hline Laminaria complanata & 514.4 & 0.04 & Pseudo-perennial \\
\hline Saccharina latissima ${ }^{\mathrm{b}}$ & 514.3 & 0.04 & Perennial \\
\hline Nereocystis luetkeana & 408.2 & 0.03 & Annual \\
\hline Pleurophycus gardneri & 333.1 & 0.02 & Annual \\
\hline Agarum cribrosum & 261.8 & 0.02 & Perennial \\
\hline Pterygophora californica & 36.7 & $<0.01$ & Perennial \\
\hline Alaria marginata & 25.0 & $<0.01$ & Annual \\
\hline Unidentified kelp & 331.3 & 0.04 & \\
\hline Other Phaeophyceae & 2285.5 & 0.17 & \\
\hline Fucus distichus & 1174.8 & 0.09 & Perennial \\
\hline Desmarestia munda & 857.9 & 0.07 & Annual \\
\hline Desmarestia ligulata & 150.6 & 0.01 & Annual \\
\hline Sargassum muticum & 66.6 & $<0.01$ & Pseudo-perennial \\
\hline Unidentified Phaeophyceae & 35.6 & $<0.01$ & \\
\hline Rhodophyta & 935.1 & 0.07 & Various \\
\hline Chlorophyta & 397.3 & 0.03 & Various \\
\hline Zostera marina & 76.2 & $<0.01$ & Perennial \\
\hline Unidentified algae & 177.6 & 0.01 & \\
\hline Total & 13120.3 & & \\
\hline
\end{tabular}

\section{DISCUSSION}

\section{The detrital macroalgal subsidy: sources and temporal dynamics}

Drift algal detritus represents a substantial flux of carbon from algal-dominated habitats to the deep subtidal zone. However, the sources and flux pathways of this material are poorly understood. In our system, attached macroalgae diminish in abundance rapidly below about $20 \mathrm{~m}$ (Fig. 2), presumably due to light limitation.

Macroalgal diversity in the shallow $(<20 \mathrm{~m})$ subtidal zone is high, but relatively few species were present in the deep $(>20 \mathrm{~m})$ subtidal algal drift. Almost half of the total drift biomass was derived from 3 species of kelp (Saccharina subsimplex, Costaria costata, and Saccharina latissima) that are only found at the shallowest edge of the subtidal zone (Table 3 ) to depths of less than 5 m below MLLW (Neushul 1965, K. H. Britton-Simmons pers. obs.). The remaining detrital biomass primarily consisted of subtidal species with broad vertical distributions. Thus, the upper margin of the shallow subtidal zone $(<5 \mathrm{~m})$ is the most important source of drift algae, probably because it has high productivity, a large standing stock of algal biomass, and is exposed to wave energy that dislodges blade fragments and entire plants. 
Deep subtidal drift was dominated by perennial brown algae (63\% of biomass). Annual brown algae made up only $19 \%$ of the drift biomass, despite their abundance in the shallow subtidal. The dominance of perennial algae has an important implication for the seasonal variability of the drift subsidy because these taxa are potentially a year-round source of algal detritus. Indeed, our data suggest that drift algae are present in the deep subtidal throughout the year, although at reduced abundance during the winter. This conclusion contrasts with the results of Rogers-Bennett et al. (1995), who found drift algae to be scarce at $23 \mathrm{~m}$ depth in Bodega Bay, California.

A key difference between the San Juan Archipelago and coastal California is that strong tidal currents have a predominant influence in the San Juan Archipelago because the inland shorelines are protected from oceanic swells. Storm waves are important in this area, but they are generated on a local scale by wind and their influence is limited to the very shallowest portions of the subtidal zone (Duggins et al. 2003, Eckman et al. 2003). Although nearshore oceanic currents exist in coastal California (Rogers-Bennett et al. 1995, Washburn et al. 1999), they are considerably weaker than the tidally generated currents that occur in our study region (e.g. Britton-Simmons et al. 2008). These differences in current and wave exposure are a possible explanation for differences in drift abundance and deep-dwelling red urchin fecundity between the 2 regions.

In California, drift availability in the subtidal zone is linked to local production of kelp fragments from nearby plants (Mattison et al. 1977, Harrold \& Reed 1985, Edwards \& Ebert 1991) and storm waves reduce subtidal drift availability by transporting it into deeper waters where it cannot be utilized by sea urchins (Dean et al. 1984, Edwards \& Ebert 1991, Dayton et al. 1992, Rogers-Bennett et al. 1995, Okey 2003). Consequently, only about $15 \%$ of sea urchins adjacent to giant kelp forests in California were in possession of drift material (Mattison et al. 1977). In contrast, more than $60 \%$ of sea urchins had drift material at most sites in the present study. In the San Juan Islands, storms and currents generate drift by breaking off algal fragments or entire thalli, and tidal currents (which typically run parallel to shore) then transport these tissues laterally along the shore. Because most drift algae are negatively buoyant, they tend to be swept along by currents near the bottom, where they can be captured by red urchins (authors' pers. obs.). Thus, in the San Juan Islands, local drift availability appears to be decoupled from local drift production by tidal currents that transport drift algae over long distances. In our view the differences between the California studies cited above and the present study are likely due to habitat differences. The present study collectively suggests that the availability of macroalgal detritus in the deep subtidal varies considerably in space and may be strongly influenced by the hydrodynamic context.

Alternatively, it is possible that latitudinal differences in algal community composition, productivity, or density could explain the Washington-California differences. For example, algal communities in California may be more dominated by species with pneumatocysts (e.g. Macrocystis) and detrital fragments from floating species can drift offshore or be deposited on beaches, fates which prevent nearshore sea urchins from utilizing them.

\section{Red sea urchin feeding and diet in the deep subtidal zone}

Both in situ feeding observations and diet content data (Table 1) indicate that drift algae is the primary food resource for deep-dwelling subtidal red urchins in the San Juan Archipelago. This conclusion is consistent with observations from other regions in the eastern Pacific where red urchins have also been observed to feed on drift algae (Mattison et al. 1977, Duggins 1981a, Dayton et al. 1984, Dean et al. 1984, Harrold \& Reed 1985, Rogers-Bennett et al. 1995). However, red (Duggins 1981b) and green (Briscoe \& Sebens 1988) sea urchins can supplement their algae diet by feeding on invertebrates in some circumstances, and one of the goals of the present study was to determine whether deep-dwelling subtidal red urchins feed on invertebrates in our system. Two independent sources of data suggest that consumption of invertebrates is uncommon. First, during our in situ feeding surveys, which included 259 red urchins at 7 sites, we never observed a red urchin feeding on an invertebrate. Second, our examination of 90 red urchin guts collected from 5 sites over an entire year revealed that benthic invertebrates were extremely uncommon in sea urchin guts (Table 1). The only invertebrate found in more than one sea urchin gut was the encrusting bryozoan Membranipora membranaceae, a common (and highly seasonal) epiphyte on kelps in this region. Although examination of $M$. membranaceae colonies from red urchin guts indicates that sea urchins are capable of digesting this bryozoan (authors' pers. obs.), ingestion of this species is probably incidental, and we think it unlikely that $M$. membranaceae contributes substantially to red urchin energetics. Gut content data provide only snapshot information about diet. Therefore we cannot exclude the possibility that some diet items were missed in our samples. Nevertheless, it appears that in this system a detrital macroalgal subsidy provides a key source of food for red urchins living 
in the deep subtidal, where attached macroalgae are absent.

One of the challenges for any organism that is reliant on a spatial subsidy is the donor-controlled nature of these fluxes (Polis et al. 1997). Because recipient species cannot influence the supply rate of spatial subsidies, they are vulnerable to the inherent temporal variability that often characterizes these inputs (e.g. Bosman \& Hockey 1986, Polis \& Hurd 1996, Sabo \& Power 2002). In our system, 2 lines of evidence suggest that sea urchins catch more drift algae than they can immediately utilize. First, at 4 of the 7 in situ feeding survey sites, some red urchins (12\% on average) possessed drift algae but were not actively feeding. Second, $17 \%$ of sea urchins we surveyed held multiple pieces of algae despite the fact that they only feed on one piece at a time. Indeed, we frequently observed groups of sea urchins that had collectively caught large quantities of algal detritus that was sufficient food for a week or more. Catching more algae than they need in the short term may buffer red urchins against periods during which drift algae is scarce. Similar mechanisms may be important in other systems were subsidy-dependent species exist.

We did not measure the movement of sea urchins in the present study and we cannot exclude the possibility that red urchins migrate between depths. Previous studies have shown that red urchin movement is linked to food availability. Red urchins are essentially sessile when drift algae are abundant and only begin to move (at a very slow rate) if food becomes scarce (Mattison et al. 1977, Russo 1979, Dean et al. 1984, Harrold \& Reed 1985). Our collective field observations of this species over many years and the results of our recent, unpublished tagging study all suggest to us that large-scale movement between depths is rare in our system.

\section{Fecundity of shallow-dwelling vs. deep-dwelling red sea urchins}

The 2 depths at which we sampled sea urchins differ dramatically in terms of standing stock of algae (Fig. 1) and thus food availability. One might reasonably expect fecundity to decline with depth, as a function of diminishing food or increasing distance from shallow habitats where macroalgae are present. Indeed, green urchins Strongylocentrotus droebachiensis are known to have smaller gonads in deep habitats (Keats et al. 1984, Bertram \& Strathmann 1998, Wahle \& Peckham 1999) and a previous study of red urchins at the same depths in California (Rogers-Bennett et al. 1995) demonstrated an $81 \%$ reduction in gonad mass in deep-dwelling red urchins. However, we found a sig- nificant difference in gonad index between depths at only one of our 5 sites (Pt. Caution, Fig. 3d) and the reduction in gonad size at depth was relatively small $(25 \%)$. Moreover, the peak gonad index of deepdwelling sea urchins at Pt. Caution was larger than that of shallow-dwelling sea urchins at 3 of the other sites. The difference between depths at Pt. Caution occurred not because deep-dwelling sea urchins had unusually small gonads, but because shallow-dwelling sea urchins had large gonads.

The large gonad size of shallow sea urchins at Pt. Caution was unexpected because this was the only population we sampled from within an urchin barren. This urchin barren is fairly large (approximately $6 \mathrm{~m}$ wide and $50 \mathrm{~m}$ long), contains high sea urchin density $\left(5.6 \mathrm{~m}^{-2}\right)$, and has persisted for at least $9 \mathrm{yr}$ at this site (K. H. Britton-Simmons pers. obs.). Previous studies have found that sea urchins in barrens have smaller gonads than those outside of barrens (Mann 1977, Harrold \& Reed 1985, Wahle \& Peckham 1999, Konar 2001, Konar \& Estes 2003), presumably due to competition for food. However, there is also evidence that sea urchins share pieces of drift algae that they have captured (Duggins 1981a) and the exploitation of some attached kelps is facilitated at high green sea urchin density (Lauzon-Guay \& Scheibling 2007). Similarly, groups of sea urchins may be able to capture and stabilize large pieces of drift algae that would be too difficult for a solitary sea urchin to manage. Although the positive effects of sea urchin density on fertilization have long been recognized (Pennington 1985, Levitan 1992, Wahle \& Peckham 1999), the potentially positive effects on food capture have been little investigated.

In this system, red urchins utilize 2 distinct habitats, shallow macroalgal communities and deep invertebrate-dominated areas. Because deep-dwelling sea urchins are abundant and have large gonads, they probably make a substantial contribution to the larval pool that repopulates all depths. However, the reliance of deep-dwelling red urchins on the drift algal subsidy means they are vulnerable to changes in the abundance or flux pathways of this resource. This vulnerability is enhanced because most drift algal biomass is contributed by only a few species. For example, in our study area Saccharina subsimplex (37\% of drift biomass) is competitively displaced by the non-native seaweed Sargassum muticum $(<1 \%$ of drift biomass; Britton-Simmons 2004). This interaction could have implications for the drift subsidy because, unlike $S$. subsimplex, S. muticum contributes little to drift biomass (it has pneumatocysts and mostly ends up as shore wrack), is relatively unpalatable to sea urchins (Britton-Simmons 2004), and its pseudo-perennial life cycle means that it cannot be a year-round source of detrital biomass. Understanding how anthropogenic 
and natural processes influence the production and movement of detrital organic matter should be a focus of future research in marine ecosystems.

In Washington, red urchins have been fished commercially for their roe since 1971 (Pfister \& Bradbury 1996). Although fishing was initially concentrated in the shallow subtidal, advances in SCUBA technology, including the use of mixed gases and dive computers, have led to increased harvesting at deeper depths in recent years (Pfister \& Bradbury 1996, B. Sizemore pers. comm.). There is presently no lower depth limit in sea urchin fishery in Washington (B. Sizemore pers. comm.). Our data suggest that due to abundant drift algae in the San Juan Islands, deep-dwelling red urchins have large gonads and consequently are a potentially valuable target for sea urchin harvesters. Importantly, a shift to fishing in deeper waters as shallow populations become depleted could mask declines in red urchin populations if harvest data do not include depth information.

Acknowledgements. For assistance in the field we thank J. Hayden-Spear. J. Harm and E. Bloczynski helped with laboratory work. We are grateful to K. Sebens, D. Duggins, C. Pfister, T. Wootton, O. Shelton, P. Bourdeau, and B. Sizemore for helpful discussions about this work. A. Hart, H. Stewart, M. Ulrich, S. Connell, and 3 anonymous reviewers made useful comments on early versions of the manuscript. Friday Harbor Laboratories provided laboratory space, boats, SCUBA facilities, and logistical support.

\section{LITERATURE CITED}

Bertram DF, Strathmann RR (1998) Effects of maternal and larval nutrition on growth and form of planktotrophic larvae. Ecology 79:315-327

Bosman AL, Hockey PAR (1986) Seabird guano as a determinant of rocky intertidal community structure. Mar Ecol Prog Ser 32:247-257

Bosman AL, Hockey PAR (1988) The influence of primary production rate on the population dynamics of Patella granularis, an intertidal limpet. PSZN I: Mar Ecol 9:181-198

Briscoe CS, Sebens KP (1988) Omnivory in Strongylocentrotus droebachiensis (Muller) (Echinodermata: Echinoidea): predation on subtidal mussels. J Exp Mar Biol Ecol 115: $1-24$

Britton-Simmons KH (2004) Direct and indirect effects of the introduced alga Sargassum muticum on benthic, subtidal communities of Washington State, USA. Mar Ecol Prog Ser 277:61-78

Britton-Simmons KH (2006) Functional group diversity, resource preemption and the genesis of invasion resistance in a community of marine algae. Oikos 113:395-401

Britton-Simmons KH, Eckman JE, Duggins DO (2008) Effect of tidal currents and tidal stage on estimates of bed size in the kelp Nereocystis luetkeana. Mar Ecol Prog Ser 355: 95-105

Bustamante RH, Branch GM, Eekhout S (1995) Maintenance of an exceptional intertidal grazer biomass in South Africa: subsidy by subtidal kelps. Ecology 76:2314-2329
Dayton PK, Currie V, Gerrodette T, Keller BD, Rosenthal R, Ven Tresca D (1984) Patch dynamics and the stability of some California kelp communities. Ecol Monogr 54: 253-289

> Dayton PK, Tegner MJ, Parnell PE, Edwards PB (1992) Temporal and spatial patterns of disturbance and recovery in a kelp forest community. Ecol Monogr 62:421-445

Dean TA, Schroeter SC, Dixon JD (1984) Effects of grazing by two species of sea urchins (Strongylocentrotus franciscanus and Lytechinus anamesus) on recruitment and survival of two species of kelp (Macrocystis pyrifera and Pterygophora californica). Mar Biol 78:301-313

Duggins DO (1981a) Interspecific facilitation in a guild of benthic marine herbivores. Oecologia 48:157-163

Duggins DO (1981b) Sea urchins and kelp: the effects of short term changes in urchin diet. Limnol Oceanogr 26:391-394

Duggins DO, Simenstad CA, Estes JA (1989) Magnification of secondary production by kelp detritus in coastal marine ecosystems. Science 245:170-173

> Duggins DO, Eckman JE, Siddon CE, Klinger T (2003) Population, morphometric and biomechanical studies of three understory kelps along a hydrodynamic gradient. Mar Ecol Prog Ser 265:57-76

> Dunton KH, Schell DM (1987) Dependence of consumers on macroalgal (Laminaria solidungula) carbon in an arctic kelp community: $\delta^{13} \mathrm{C}$ evidence. Mar Biol 93:615-625

> Eckman JE, Duggins DO, Siddon CE (2003) Current and wave dynamics in the shallow subtidal: implications to the ecology of understory and surface-canopy kelps. Mar Ecol Prog Ser 265:45-56

Edwards PB, Ebert TA (1991) Plastic responses to limited food availability and spine damage in the sea urchin Stronglycentrotus purpuratus (Stimpson). J Exp Mar Biol Ecol 145: $205-220$

Engqvist L (2005) The mistreatment of covariate interaction terms in linear model analyses of behavioral and evolutionary ecology studies. Anim Behav 70:967-971

Gabrielson PG, Widdowson TB, Lindstrom SC (2006) Keys to the seaweeds and seagrasses of southeast Alaska, British Columbia, Washington and Oregon. Phycological Contribution No. 7, University of British Columbia, Vancouver

Harrold C, Reed DC (1985) Food availability, sea urchin grazing, and kelp forest community structure. Ecology 66: 1160-1169

Harrold C, Light K, Lisin S (1998) Organic enrichment of submarine-canyon and continental-shelf benthic communities by macroalgal drift imported from nearshore kelp forests. Limnol Oceanogr 43:669-678

Josselyn MN, Cailliet GM, Niesen TM, Cowen R, Hurley AC, Connor J, Hawes S (1983) Composition, export and faunal utilization of drift vegetation in the Salt River Submarine Canyon. Estuar Coast Shelf Sci 17:447-465

> Kaehler S, Pakhomov EA, Kalin RM, Davis S (2006) Trophic importance of kelp-derived suspended particulate matter in a through-flow sub-Antarctic system. Mar Ecol Prog Ser 316:17-22

> Keats DW, Steele DH, South GR (1984) Depth-dependent reproductive output of the green sea urchin, Strongylocentrotus droebachiensis (O. F. Müller), in relation to the nature and availability of food. J Exp Mar Biol Ecol 80: $77-91$

- Konar B (2001) Seasonal changes in subarctic sea urchin populations from different habitats. Polar Biol 24:754-763

> Konar B, Estes JA (2003) The stability of boundary regions between kelp beds and deforested areas. Ecology 84: $174-185$

Lauzon-Guay J, Scheibling RE (2007) Behavior of sea urchin 
Strongylocentrotus droebachiensis grazing fronts: foodmediated aggregation and density-dependent facilitation. Mar Ecol Prog Ser 329:191-204

Leigh EG, Paine RT, Quinn JF, Suchanek TH (1987) Wave energy and intertidal productivity. Proc Natl Acad Sci USA 84:1314-1318

Levitan DR (1992) How distribution and abundance influence fertilization success in the sea urchin Strongylocentrotus franciscanus. Ecology 73:248-254

Mann KH (1977) Destruction of kelp-beds by sea urchins: A cyclical phenomenon or irreversible degradation? Helgol Wiss Meeresunters 30:455-467

Mann KH (1988) Production and use of detritus in various freshwater, estuarine, and coastal marine ecosystems. Limnol Oceanogr 33:910-930

Mattison JE, Trent JD, Shanks AL, Akin TB, Pearse JS (1977) Movement and feeding activity of red sea urchins (Strongylocentrotus franciscanus) adjacent to a kelp forest. Mar Biol 39:25-30

Menzies RJ, Zaneveld JS, Pratt RM (1967) Transported turtle grass as a source of organic enrichment of the abyssal sediments off North Carolina. Deep-Sea Res 14:111-112

> Nakano S, Murakami M (2001) Reciprocal subsidies: dynamic interdependence between terrestrial and aquatic food webs. Proc Natl Acad Sci USA 98:166-170

Neushul M (1965) Scuba diving studies of the vertical distribution of benthic marine plants. Proc Fifth Mar Biol Symp, Acta Universitatis Gothoburgensis, Botanica Gothoburgensa III, p 161-176

Neushul M (1967) Studies of subtidal marine vegetation in western Washington. Ecology 48:83-94

> Okey TA (2003) Macrobenthic colonist guilds and renegades in Monterey Canyon (USA) drift algae: partitioning multidimensions. Ecol Monogr 73:415-440

Orr M, Zimmer M, Jelinski DE, Mews M (2005) Wrack deposition on different beach types: spatial and temporal variation in the pattern of subsidy. Ecology 86:1496-1507

Pennington JT (1985) The ecology of fertilization of echinoid eggs: the consequence of sperm dilution, adult aggregation, and synchronous spawning. Biol Bull 169:417-430

Pfister CA, Bradbury A (1996) Harvesting red sea urchins: recent effects and future predictions. Ecol Appl 6(1): 298-310

Polis GA, Hurd SD (1995) Extraordinarily high spider densities on islands: flow of energy from the marine to terrestrial food webs and the absence of predation. Proc Natl Acad Sci USA 92:4382-4386

Editorial responsibility: Sean Connell,

Adelaide, Australia
Polis GA, Hurd SD (1996) Linking marine and terrestrial food webs: allochthonous input from the ocean supports high secondary productivity on small islands and coastal land communities. Am Nat 147:396-423

Polis GA, Anderson WB, Holt RD (1997) Toward an integration of landscape and food web ecology: the dynamics of spatially subsidized food webs. Annu Rev Ecol Syst 28:289-316

> Rodriguez SR (2003) Consumption of drift kelp by intertidal populations of the sea urchin Tetrapygus niger on the central Chilean coast: possible consequences at different ecological levels. Mar Ecol Prog Ser 251:141-151

Rogers-Bennett L, Bennett WA, Fastenau HC, Dewees CM (1995) Spatial variation in red sea urchin reproduction and morphology: implications for harvest refugia. Ecol Appl 5: $1171-1180$

Rose MD, Polis GA (1998) The distribution and abundance of coyotes: the effects of allochthonous food subsidies from the sea. Ecology 79:998-1007

Russo AR (1979) Dispersion and food differences between two populations of the sea urchin Strongylocentrotus franciscanus. J Biogeogr 6:407-414

Sabo JL, Power ME (2002) River-watershed exchange: effects of riverine subsidies on riparian lizards and their terrestrial prey. Ecology 83:1860-1869

Sanchez-Pinero F, Polis GA (2000) Bottom-up dynamics of allochthonous input: direct and indirect effects of seabirds on islands. Ecology 81:3117-3132

> Stapp P, Polis GA (2003) Marine resources subsidize insular rodent populations in the Gulf of California, Mexico. Oecologia 134:496-504

Suchanek TH, Williams SL, Ogden JC, Hubbard DK, Gill IP (1985) Utilization of shallow-water seagrass detritus by Caribbean deep-sea macrofauna: $\delta^{13} \mathrm{C}$ evidence. DeepSea Res Part A 32:201-214

> Vetter EW, Dayton PK (1999) Organic enrichment by macrophyte detritus, and abundance patterns of megafaunal populations in submarine canyons. Mar Ecol Prog Ser 186: 137-148

> Wahle RA, Peckham SH (1999) Density-related reproductive trade-offs in the green sea urchin, Strongylocentrotus droebachiensis. Mar Biol 134:127-137

> Washburn L, Stone S, MacIntyre S (1999) Dispersion of produced water in a coastal environment and its biological implications. Cont Shelf Res 19:57-78

Witman JD (1988) Stability of Atlantic kelp forests. Trends Ecol Evol 3:285-286

Submitted: September 19, 2008; Accepted: April 1, 2009

Proofs received from author(s): May 12, 2009 